\title{
The significance of estrogen receptor $\beta$ in 301 surgically treated non-small cell lung cancers
}

\author{
Chen-Tu Wu, MD, ${ }^{a}$ Yih-Leong Chang, MD, ${ }^{a}$ Jin-Yuan Shih, MD, PhD, ${ }^{b}$ and Yung-Chie Lee, MD, PhD ${ }^{c}$
}

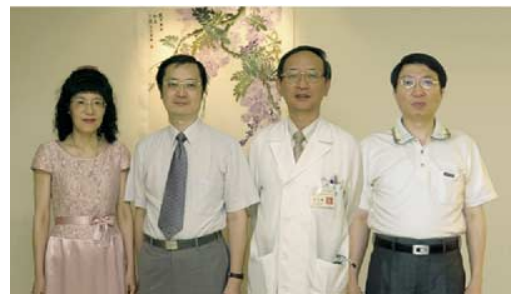

Chang, Wu, Lee, Shih (left to right)
Objective: Estrogen receptor expression in lung cancer has been understudied, particularly in light of its potential biologic importance in the epidemic of lung cancer in women. The expression of estrogen receptors was investigated to better understand the possible role of sex hormones in lung cancer.

Methods: A total of 301 patients with surgically resected non-small cell lung cancers of stages I to III were explored. Sections of paraffin-embedded tumor samples were stained with estrogen receptor $\alpha$ and estrogen receptor $\beta$ antibodies. Tumors with moderate-to-strong nuclear staining in at least 50\% of the tumor cells were scored as positive for overexpression.

Results: The overall frequency of overexpression for estrogen receptor $\beta$ was $45.8 \%$ $(138 / 301)$. It was detected most frequently in female patients (in $54.3 \%$ of 127 tumors vs $39.7 \%$ of 174 tumors in men, $P=.012$ ). However, there was no estrogen receptor $\alpha$ nuclear staining detectable in non-small cell lung cancers. Interestingly, a significant correlation between estrogen receptor $\beta$ expression, stage of disease, grade of differentiation, smoking status, vascular invasion, and survival in patients with stage II and III disease was found. By using multivariate analysis of survival among patients with stage II and III disease, estrogen receptor $\beta$ overexpression, stage II tumor, well differentiation, nonsmoking status, and lack of vascular invasion were significantly favorable prognostic factors.

Conclusions: The results presented here show for the first time that immunohistochemical expression of estrogen receptor $\beta$ can be used as a prognostic indicator in patients with surgically resected stage II and III non-small cell lung cancers. These observations might offer a possibility for hormonal therapy in patients with lung cancer.

From the Departments of Pathology, ${ }^{\mathrm{a}}$ Internal Medicine, ${ }^{\mathrm{b}}$ and Surgery and Traumatology, ${ }^{\mathrm{c}}$ National Taiwan University Hospital and National Taiwan University College of Medicine, Taipei, Taiwan.

Supported by National Science Council, ROC (NSC 92-2314-B-002-255 and NSC 93-2314-B-002-044).

Received for publication Feb 15, 2005; revisions received May 3, 2005; accepted for publication June 16, 2005.

Address for reprints: Yung-Chie Lee, MD, $\mathrm{PhD}, 6 \mathrm{~F}-1$, 99, Section 3, Roosevelt Rd, Taipei 10646, Taiwan (E-mail: damu@ha. mc.ntu.edu.tw).

J Thorac Cardiovasc Surg 2005;130:979-86

$0022-5223 / \$ 30.00$

Copyright $\odot 2005$ by The American Association for Thoracic Surgery

doi:10.1016/j.jtcvs.2005.06.012
$\mathrm{L}$ ung cancer is one of the leading causes of cancer death in Taiwan ${ }^{1}$ and the most common cause of cancer death in Western countries. ${ }^{2}$ With the 5 -year survival rate at only about $10 \%$, lung cancer causes more than 6000 deaths per year in Taiwan. The majority of these tumors are non-small cell lung carcinomas (NSCLCs), of which adenocarcinoma is the most common histologic type. . $^{3,4}$

Although cigarette smoking is the major risk factor, most people who smoke do not have lung cancer. Only approximately $3 \%$ of lung cancers occurred in nonsmokers ${ }^{5}$ in the Western world, and the majority of female patients with lung cancer were nonsmokers in Taiwan. ${ }^{6}$ Therefore factors other than cigarette smoking must also have a role in the pathogenesis of lung cancer. Such factors might be environmental (water and air pollution or occupational exposure) or host related (genetic or nutritional).

Sex hormones might be a host-related factor that influences the development of lung cancer in men and women. Estrogen receptors (ERs) are normally found in the breast and tissues of the female reproductive tract. Additionally, they are sometimes found in the neoplasms of these tissues. ${ }^{7}$ The existence of ERs has also been 
demonstrated in a wide array of neoplasms, including meningiomas and primary brain tumors, malignant melanomas, sarcomas, carcinomas of the head and neck, thyroid gland, lungs, liver, pancreas, stomach, colon, and prostate gland. ${ }^{8}$

The human ER, now termed ER $\alpha$, was first cloned in 1986. For the next 10 years, research on its ligand-dependent effects focused on the binding of estrogen to one cognate receptor. ${ }^{9}$ In 1996, a second isoform of ER, referred to as ER $\beta$, was discovered, which redefined concepts of the estrogen signaling pathway. ${ }^{10}$ The ER $\beta$ protein has similarities to the classical ER $\alpha$ in terms of structure and function. The tissue distribution of these 2 receptors is not identical, but it appears to overlap in some cases. ${ }^{11} \mathrm{ER} \alpha$ and $\mathrm{ER} \beta$ also differ in their effect on transcription at activator protein-1 (AP-1) sites. ${ }^{12}$ Whereas $\mathrm{ER} \alpha$ as a ligand to estradiol activates transcription at AP-1 sites, ER $\beta$ as a ligand to estradiol inhibits transcription at AP-1 sites. This evidence suggests that $\mathrm{ER} \alpha$ and $\mathrm{ER} \beta$ might be regulated by distinct mechanisms and play different roles in gene regulation, although sharing functional characteristics. Thus far, only limited data are available on the activity and expression of ERs in human lung neoplasms. Because there have been conflicting results in the literature, possibly as a result of the small number of tumors studied, the role of ERs has remained obscure. ${ }^{8,13-19}$

The evolution from nonselective methods of detection of ERs (biochemical assay) to a more reliable method making use of monoclonal antibodies (immunohistochemical assay) has allowed the identification of the receptors in their functional site, the nucleus. The immunohistochemical assay is more selective and specific because of the use of monoclonal antibodies reacting with epitopes that offer only minimal variability. In the present study, the expression of $\operatorname{ER} \alpha$ and $\mathrm{ER} \beta$, as determined by means of immunohistochemistry, in 301 surgically resected NSCLCs was investigated. These findings were correlated with the clinicopathologic features, including sex, smoking history, histologic type and differentiation, tumor size, stage, vascular invasion, lymph node metastasis, and survival.

\section{Materials and Methods \\ Patients and Tumor Specimen}

Three hundred one NSCLC specimens were obtained from patients who underwent complete surgical resection at National Taiwan University hospital between January 1990 and December 2001. The study was approved by the Research Ethics Committee of this hospital. These patients were not treated with neoadjuvant chemotherapy and irradiation therapy. All specimens were formalin fixed and sectioned for microscopic examination after applying hematoxylin and eosin stain. Histologic diagnosis and pathologic features were obtained, including tumor cell type, degree of differentiation, vascular invasion, and regional lymph node metastasis. Pathologic staging was performed according to the international staging system for lung cancer, ${ }^{20}$ which was based on tumor size, location and involvement, and the presence of lymph node metastasis. Adenosquamous carcinomas were not included in the clas- sification of histologic type and grade of differentiation because of the discrepancy in each tumor. The patient numbers in some parameters might be less because the information was not available in a few cases. The women were grouped into 2 categories on the basis of the average US menopausal age of 51 years, as defined by the American College of Obstetricians and Gynecologists. Premenopausal was defined as women aged less than 51 years and postmenopausal was defined as women aged at least 51 years. ${ }^{21}$ The follow-up period ranged from 2 to 168 months (median survival, 41 months).

\section{Immunohistochemistry}

For immunohistochemical demonstration of $\mathrm{ER} \beta$ or $\mathrm{ER} \alpha$ expression in the tumor tissue, $4-\mu \mathrm{m}$-thick sections from each formalinfixed, paraffin-embedded tissue block were dewaxed with xylene and rehydrated through a graded series of ethanol.

The sections for immunohistochemistry of the ER $\beta$ and ER $\alpha$ expression were autoclaved in $0.01 \mathrm{~mol} / \mathrm{L}$ citrate buffer $(\mathrm{pH} \mathrm{6.0)}$ at $121^{\circ} \mathrm{C}$ for 10 minutes $(\mathrm{ER} \beta)$ and in EDTA buffer $(\mathrm{pH} 8.0)$ for 8 minutes $(\mathrm{ER} \alpha)$. They were treated with $3 \% \mathrm{H}_{2} \mathrm{O}_{2}$-methanol solution to reduce endogenous peroxidase activity. These were then incubated with normal goat serum to reduce nonspecific antibody binding and were subsequently subjected to the primary antibody reaction. The antibodies for $\operatorname{ER} \beta(1: 100$, BioGenex) and $\operatorname{ER} \alpha$ $(1: 30$, BioGenex) were left to react with the sections overnight $(\operatorname{ER} \beta)$ and for 2 hours $(\operatorname{ER} \alpha)$ at room temperature. Detection of the immunoreactive staining was carried out by using the avidin-biotinperoxidase complex method, according to the manufacturer's instructions (Dako Corp). The primary antibody was replaced with bovine serum albumin to check for nonspecific staining by the avidin-biotinperoxidase complex detection system. The sections were then subjected to a color reaction with $0.05 \%$ 3,3-diaminobenzidine in 0.05 $\mathrm{mol} / \mathrm{L}$ Tris base $(\mathrm{pH} 7.6)$ containing $0.01 \% \mathrm{H}_{2} \mathrm{O}_{2}$ and were lightly counterstained with hematoxylin.

\section{Assessment of ER Expression}

By using an infiltrating ductal carcinoma of the breast with a high content of ER $\beta$ and ER $\alpha$ as a positive control, the expression of $\operatorname{ER} \beta$ and $\operatorname{ER} \alpha$ for each tumor was assessed. Tumors were considered to be positive when there was moderate-to-strong nuclear staining of more than $50 \%$ of the neoplastic cells. Two independent pathologists (C-TW and Y-LC) were involved in the assessment of expression.

\section{Statistical Analysis}

The correlation between various clinical or pathologic parameters and the expression of ER $\beta$ was analyzed by using the Pearson $\chi^{2}$ test. Survival curves were estimated by using the Kaplan-Meier method. The log-rank test was used to compare survival curves. Cox proportional hazards regression was used to model survival with $\operatorname{ER} \beta$ overexpression and clinicopathologic variables typically associated with prognosis. The following factors were modeled in a univariate fashion: sex (male or female); histologic type (squamous cell carcinomas or bronchioloalveolar carcinomas and adenocarcinomas); tumor size ( $>3 \mathrm{~cm}$ or $\leq 3 \mathrm{~cm}$ ); stage (I, II, and III); grade of differentiation (well, moderately, or poorly differentiated); smoking status (smokers or nonsmokers); vascular invasion (absent or present); and ER $\beta$ overexpression (positive or negative). 
TABLE 1. Relationship between patient demographics and smoking history

\begin{tabular}{|c|c|c|c|c|c|}
\hline Parameters & $\begin{array}{c}\text { No. of } \\
\text { patients }\end{array}$ & $\begin{array}{l}\text { No. of patients with } \\
\text { smoking history }\end{array}$ & $\begin{array}{c}\text { Smokers } \\
(\%)\end{array}$ & $\begin{array}{c}\text { Nonsmokers } \\
(\%)\end{array}$ & $P$ value \\
\hline Total patients & 301 & & & & \\
\hline \multicolumn{6}{|l|}{ Sex } \\
\hline Male & 174 & 164 & $120(73.2)$ & $44(26.8)$ & \\
\hline Female & 127 & 126 & $11(8.7)$ & $115(91.3)$ & $<.001$ \\
\hline \multicolumn{6}{|l|}{ Histologic type } \\
\hline Squamous cell carcinoma & 90 & & & & \\
\hline Male & 77 & 72 & $65(90.3)$ & $7(9.7)$ & \\
\hline Female & 13 & 13 & $4(30.8)$ & $9(69.2)$ & $<.001$ \\
\hline Adenocarcinoma & 194 & & & & \\
\hline Male & 85 & 80 & $49(61.3)$ & $31(38.8)$ & \\
\hline Female & 109 & 108 & $7(6.5)$ & $101(93.5)$ & $<.001$ \\
\hline Adenosquamous carcinoma & 17 & & & & \\
\hline Male & 12 & 12 & $6(50)$ & $6(50)$ & \\
\hline Female & 5 & 5 & $0(0)$ & $5(100)$ & .049 \\
\hline \multicolumn{6}{|l|}{ Age (y) } \\
\hline$\leq 50$ & 41 & 38 & $12(31.6)$ & $26(68.4)$ & \\
\hline$>50$ & 260 & 252 & $119(47.2)$ & $133(52.8)$ & .071 \\
\hline
\end{tabular}

A multivariate Cox proportional hazards regression model was fit with those variables that demonstrated statistical significance $(P<$ $.050)$ in the univariate models. SPSS version 10.0 software (SPSS Inc) was used for all analyses.

\section{Results}

\section{Patient Demographics}

Of the 301 patients in this study, 174 were men, and 127 were women. Their ages ranged from 30 to 83 years, with a mean age of 63 years. All patients underwent complete surgical resection with regional lymph node dissection.

The majority of the male patients were smokers (120/164 $[73.2 \%])$, whereas the majority of the female patients were nonsmokers $(115 / 126$ [91.3\%], $P<.001)$. There were 90 squamous cell carcinomas, 194 adenocarcinomas, and 17 adenosquamous carcinomas. Among patients with squamous cell carcinomas, most of the male patients were smokers $(65 / 72$ [90.3\%]), whereas the female patients were predominantly nonsmokers $(9 / 13$ [69.2\%], $P<.001)$. Among patients with adenocarcinomas, most of the male patients were smokers (49/80 [61.3\%]), and 101 (93.5\%) of 108 female patients were nonsmokers. This difference was also statistically significant $(P<.001$, Table 1$)$.

\section{Correlations Between ER $\beta$ Expression and Clinicopathologic Features}

In the current study, $\mathrm{ER} \beta$ nuclear reactivity was detected in $138(45.8 \%)$ of the 301 lung cancers, usually of moderateto-strong intensity. The remaining $163(54.2 \%)$ lung cancers were characterized by complete absence of nuclear staining or $50 \%$ or less immunoreactivity. The relationship between clinical parameters or pathologic characteristics and the frequency of $E R \beta$ reactivity is shown in Table 2. Higher $\mathrm{ER} \beta$ expression was noted in female patients, nonsmokers, patients with tumors of $3 \mathrm{~cm}$ or smaller, patients without lymph node metastasis, and patients with tumors with a lower grade of differentiation.

Overexpression of ER $\beta$ was significantly more common in tumors occurring in nonsmokers $(53.5 \%)$ than in those of smokers $(36.6 \%, P=.004)$. Among the nonsmokers, higher $\mathrm{ER} \beta$ expression was observed more frequently in female patients $(58.3 \%)$ than in male patients $(40.9 \%)$, and such a difference was also statistically significant $(P=.050)$. In both squamous cell carcinoma and adenocarcinoma (including bronchioloalveolar carcinoma), the overexpression of $\mathrm{ER} \beta$ was observed preferentially in well-differentiated subtypes $(P<.001)$.

Differences in ER $\beta$ expression were not statistically significant $(P=.579)$ between the premenopausal and postmenopausal groups of female patients.

\section{Correlations Between ER $\beta$ Expression,}

Clinicopathologic Features, and Survival

The influence of various clinicopathologic parameters on overall patient survival was analyzed (Table 3). By using univariate analysis of survival, significantly better prognostic indicators included tumors of $3 \mathrm{~cm}$ or smaller, earlystage tumors, tumors with a lower grade of differentiation, tumors without vascular invasion, and increased levels of $\mathrm{ER} \beta$ expression. By using multivariate analysis, early-stage tumors, tumors with a lower grade of differentiation, and tumors without vascular invasion remained as statistically significant prognostic factors indicating better survival. 
TABLE 2. Frequency of ER $\beta$ expression with relation to clinical parameters and pathologic characteristics

\begin{tabular}{|c|c|c|c|c|}
\hline Parameters & No. of patients* & $\operatorname{ER} \beta>50 \%(\%)$ & $\operatorname{ER} \beta \leq 50 \%(\%)$ & $P$ value \\
\hline Patient no. & 301 & $138(45.8)$ & $163(54.2)$ & \\
\hline \multicolumn{5}{|l|}{ Menopausal age (y) } \\
\hline$\leq 50$ (premenopausal) & 20 & $12(60.0)$ & $8(40.0)$ & .579 \\
\hline$>50$ (postmenopausal) & 107 & $57(53.3)$ & $50(46.7)$ & \\
\hline \multicolumn{5}{|l|}{ Sex } \\
\hline Male & 174 & $69(39.7)$ & $105(60.3)$ & .012 \\
\hline Female & 127 & $69(54.3)$ & $58(45.7)$ & \\
\hline \multicolumn{5}{|l|}{ Smoking history } \\
\hline Positive & 131 & $48(36.6)$ & $83(63.4)$ & .004 \\
\hline Negative & 159 & $85(53.5)$ & $74(46.5)$ & \\
\hline \multicolumn{5}{|l|}{ Histologic type† } \\
\hline Squamous cell carcinoma & 90 & $37(41.1)$ & $53(58.9)$ & .163 \\
\hline Adenocarcinoma & 194 & $97(50.0)$ & $97(50.0)$ & \\
\hline \multicolumn{5}{|l|}{ Tumor size } \\
\hline$\leq 3 \mathrm{~cm}$ & 127 & $68(53.5)$ & $59(46.5)$ & .022 \\
\hline$>3 \mathrm{~cm}$ & 174 & $70(40.2)$ & $104(59.8)$ & \\
\hline \multicolumn{5}{|l|}{ Tumor stage } \\
\hline I & 114 & $61(53.5)$ & $53(46.5)$ & .112 \\
\hline II & 67 & $27(40.3)$ & $40(59.7)$ & \\
\hline III & 120 & $50(41.7)$ & $70(58.3)$ & \\
\hline \multicolumn{5}{|l|}{ Vacular invasion } \\
\hline Positive & 70 & $34(48.6)$ & $36(51.4)$ & .602 \\
\hline Negative & 231 & $104(45.0)$ & $127(55.0)$ & \\
\hline \multicolumn{5}{|l|}{ Lymph node metastasis } \\
\hline Positive & 168 & $66(39.3)$ & $102(60.7)$ & .010 \\
\hline Negative & 133 & $72(54.1)$ & $61(45.9)$ & \\
\hline \multicolumn{5}{|l|}{ Grade of differentiationt } \\
\hline Well & 106 & $66(62.3)$ & $40(37.7)$ & $<.001$ \\
\hline Moderate & 149 & $59(39.6)$ & $90(60.4)$ & \\
\hline Poor & 29 & $9(31.0)$ & $20(69.0)$ & \\
\hline
\end{tabular}

*Some of the patients lack information. †Adenosquamous carcinomas are not included.

These patients were then divided according to their tumor stage. In patients with stage I disease, there were no significant prognostic indicators, including $\operatorname{ER} \beta$ overexpression, determined by using univariate analysis of survival. A total of 187 patients had stage II and III tumors. An analysis of the effect of various clinicopathologic factors on patient survival was performed for these patients with stage II and III disease (Table 4). By using univariate analysis, stage II tumors, tumors with a lower grade of differentiation, nonsmoking status, tumors without vascular invasion, and increased expression of ER $\beta$ were found to be significantly better prognostic indicators. By using multivariate analysis, all 5 factors remained statistically significant favorable prognostic indicators (Figure 1).

\section{ER $\alpha$ Expression}

In contrast, there was no $\mathrm{ER} \alpha$ nuclear staining in any NSCLCs. Only 8 cases demonstrated cytoplasmic staining. The staining intensity of most cases was weak.

\section{Discussion}

The presence of ERs in human lung cancers has been controversial for many years. Some studies have been performed to assess the expression of ERs in human lung cancers to explain sex differences in incidence, histology, and prognosis of human NSCLCs between female and male patients. ${ }^{5,8,13,14,22}$ However, reported values have varied widely, and the involvement of this receptor in lung physiology, pathology, or both remains unclear.

ERs, members of the nuclear steroid receptor superfamily, mediate cellular response to estrogen. Two ERs have been identified, $\mathrm{ER} \alpha$ and $\mathrm{ER} \beta$, which are encoded by separate genes. ER $\beta$ is localized on human chromosome 14, whereas $\mathrm{ER} \alpha$ is located on chromosome $6 .{ }^{23}$ These proteins function as sequence-specific, ligand-activated transcription factors. Both receptors possess several distinct functional domains, including a central DNA-binding domain that is highly conserved between ER $\alpha$ and ER $\beta .^{24}$ These functional differences could be due to the dissimilarities in 
TABLE 3. Correlations between ER $\beta$ expression, clinicopathologic features, and survival in 301 patients with stage I to III disease

\begin{tabular}{|c|c|c|c|c|c|c|c|c|}
\hline \multirow[b]{2}{*}{ Variables } & \multirow[b]{2}{*}{$\begin{array}{c}\text { No. of } \\
\text { patients* }\end{array}$} & \multirow[b]{2}{*}{$\begin{array}{l}\text { No. of } \\
\text { deaths }\end{array}$} & \multicolumn{3}{|c|}{ Univariate } & \multicolumn{3}{|c|}{ Multivariate } \\
\hline & & & $\begin{array}{c}\text { Hazard } \\
\text { ratio }\end{array}$ & $95 \% \mathrm{Cl}$ & $P$ value & $\begin{array}{c}\text { Hazard } \\
\text { ratio }\end{array}$ & $95 \% \mathrm{Cl}$ & $P$ value \\
\hline \multicolumn{9}{|l|}{ ER $\beta$ overexpression } \\
\hline Negative & 163 & 84 & 1.000 & & & 1.000 & & \\
\hline Positive & 138 & 55 & 0.672 & $0.478-0.945$ & .022 & 0.719 & $0.504-1.026$ & .069 \\
\hline \multicolumn{9}{|l|}{ Size } \\
\hline$\leq 3 \mathrm{~cm}$ & 127 & 48 & 1.000 & & & & & \\
\hline$>3 \mathrm{~cm}$ & 174 & 91 & 1.776 & $1.248-2.526$ & .001 & & & \\
\hline \multicolumn{9}{|l|}{ Stage } \\
\hline I & 114 & 21 & 1.000 & & & 1.000 & & \\
\hline II & 67 & 33 & 3.635 & $2.082-6.349$ & $<.001$ & 3.084 & $1.732-5.489$ & $<.001$ \\
\hline III & 120 & 85 & 6.870 & $4.201-11.236$ & $<.001$ & 6.021 & $3.577-10.136$ & $<.001$ \\
\hline \multicolumn{9}{|l|}{ Differentiationt } \\
\hline Well & 106 & 35 & 1.000 & & & 1.000 & & \\
\hline Moderate & 149 & 75 & 1.984 & $1.322-2.977$ & .001 & 1.372 & $0.906-2.079$ & .136 \\
\hline Poor & 29 & 19 & 3.229 & $1.837-5.676$ & $<.001$ & 2.895 & $1.630-5.142$ & $<.001$ \\
\hline \multicolumn{9}{|l|}{ Vascular invasion } \\
\hline Negative & 231 & 93 & 1.000 & & & 1.000 & & \\
\hline Positive & 70 & 46 & 2.355 & $1.644-3.373$ & $<.001$ & 1.749 & $1.186-2.580$ & .005 \\
\hline \multicolumn{9}{|l|}{ Sex } \\
\hline Female & 127 & 52 & 1.000 & & & & & \\
\hline Male & 174 & 87 & 1.387 & $0.983-1.958$ & .063 & & & \\
\hline \multicolumn{9}{|l|}{ Smoking history } \\
\hline Negative & 159 & 66 & 1.000 & & & & & \\
\hline Positive & 131 & 66 & 1.403 & $0.997-1.974$ & .052 & & & \\
\hline \multicolumn{9}{|l|}{ Histologic type } \\
\hline Squamous cell carcinoma & 90 & 45 & 1.000 & & & & & \\
\hline Adenocarcinoma & 194 & 84 & 0.778 & $0.539-1.121$ & .177 & & & \\
\hline
\end{tabular}

*Some of the patients lack information. $†$ Adenosquamous carcinomas are not included.

the N-terminal domains, suggesting that these 2 receptors interact with different sets of proteins. The tissue distribution of $\mathrm{ER} \alpha$ is also different from that of $\mathrm{ER} \beta$, suggesting that these proteins function in a tissue-specific manner. ${ }^{11}$

$\operatorname{ER} \beta$ has been shown to be expressed and functional in most human NSCLC cell lines and cells derived from normal lung and tissues. ${ }^{2,18,19}$ Most investigations have been performed at the mRNA expression level with reverse transcriptase-polymerase chain reaction analysis; however, very few studies have applied immunohistochemistry. ${ }^{25}$ In the present study a positive correlation between $\mathrm{ER} \beta$ protein overexpression and female sex, nonsmoking status, tumors of $3 \mathrm{~cm}$ or smaller, absence of lymph node metastasis, and tumors with a lower grade of differentiation was noted. We found positive $\mathrm{ER} \beta$ expression in squamous cell carcinomas and adenocarcinomas. Although it has been recognized that $\mathrm{ER} \beta$ expression is found to be higher in tumors from women ${ }^{15}$ and adenocarcinomas, ${ }^{18}$ other authors have also reported positive ER expressions in both squamous cell carcinomas and adenocarcinomas. ${ }^{22,26,27}$
Bronchogenic carcinomas of all major cell types are thought to arise from a common precursor cell and share certain genetic abnormalities (ie, deletions or rearrangements of the short arm of chromosome 3$).{ }^{28}$ Therefore it is not surprising that lung cancers of different cell types share a property like positive sex hormone receptor status.

The correlation between ER $\beta$ and various clinicopathologic factors has revealed that $\mathrm{ER} \beta$ is expressed predominantly in well-differentiated and small-sized lung cancers. This result indicates that the expression of $\mathrm{ER} \beta$ is lost during dedifferentiation of the tumor cells. It is also noted that $\operatorname{ER} \beta$ is tightly associated with lymph node status. This suggests that the loss of ER $\beta$ expression might be an indicator of a tumor phenotype with high metastatic potential. Such a role is in agreement with the findings of metastatic tendency in the axillary lymph nodes of breast cancers. ${ }^{29}$ This implies that $\mathrm{ER} \beta$ might play a gatekeeper role by inhibiting invasion and proliferation and maintaining the low biologic aggressiveness and might be related to suppression of tumor growth. ${ }^{30}$ 
TABLE 4. Correlations between ER $\beta$ expression, clinicopathologic features, and survival in 187 patients with stage II and III disease

\begin{tabular}{|c|c|c|c|c|c|c|c|c|}
\hline \multirow[b]{2}{*}{ Variables } & \multirow[b]{2}{*}{$\begin{array}{l}\text { No. of } \\
\text { patients* }\end{array}$} & \multirow[b]{2}{*}{$\begin{array}{l}\text { No. of } \\
\text { deaths }\end{array}$} & \multicolumn{3}{|c|}{ Univariate } & \multicolumn{3}{|c|}{ Multivariate } \\
\hline & & & $\begin{array}{c}\text { Hazard } \\
\text { ratio }\end{array}$ & $95 \%$ CI & $P$ value & $\begin{array}{c}\text { Hazard } \\
\text { ratio }\end{array}$ & $95 \%$ CI & $P$ value \\
\hline \multicolumn{9}{|l|}{ ER $\beta$ overexpression } \\
\hline Negative & 110 & 77 & 1.000 & & & 1.000 & & \\
\hline Positive & 77 & 41 & 0.581 & $0.397-0.849$ & .005 & 0.662 & $0.439-0.999$ & .049 \\
\hline \multicolumn{9}{|l|}{ Stage } \\
\hline II & 67 & 33 & 1.000 & & & 1.000 & & \\
\hline III & 120 & 85 & 1.880 & $1.251-2.823$ & .002 & 2.081 & $1.304-3.321$ & .002 \\
\hline \multicolumn{9}{|l|}{ Differentiationt } \\
\hline Well & 53 & 28 & 1.000 & & & 1.000 & & \\
\hline Moderate & 102 & 65 & 1.523 & $0.977-2.374$ & .063 & 1.183 & $0.745-1.878$ & .476 \\
\hline Poor & 21 & 16 & 2.697 & $1.452-5.007$ & .002 & 2.233 & $1.158-4.305$ & .016 \\
\hline \multicolumn{9}{|l|}{ Smoking status } \\
\hline Nonsmokers & 98 & 57 & 1.000 & & & 1.000 & & \\
\hline Smokers & 82 & 57 & 1.651 & $1.142-2.387$ & .008 & 1.762 & $1.168-2.659$ & .007 \\
\hline \multicolumn{9}{|l|}{ Vascular invasion } \\
\hline Negative & 131 & 75 & 1.000 & & & 1.000 & & \\
\hline Positive & 56 & 43 & 1.830 & $1.248-2.684$ & .002 & 1.639 & $1.079-2.490$ & .021 \\
\hline \multicolumn{9}{|l|}{ Sex } \\
\hline Female & 76 & 45 & 1.000 & & & & & \\
\hline Male & 111 & 73 & 1.384 & $0.954-2.007$ & .087 & & & \\
\hline \multicolumn{9}{|l|}{ Histologic type $†$} \\
\hline Squamous cell carcinoma & 58 & 36 & 1.000 & & & & & \\
\hline Adenocarcinoma & 118 & 73 & 0.876 & $0.587-1.308$ & .518 & & & \\
\hline \multicolumn{9}{|l|}{ Size } \\
\hline$\leq 3 \mathrm{~cm}$ & 53 & 32 & 1.000 & & & & & \\
\hline$>3 \mathrm{~cm}$ & 134 & 86 & 1.307 & $0.870-1.964$ & .197 & & & \\
\hline
\end{tabular}

*Some of the patients lack information. $†$ Adenosquamous carcinomas are not included.

Of particular interest is our finding that patients with stage II tumors, a lower grade of differentiation, nonsmoking status, tumors without vascular invasion, and overexpression of ER $\beta$ have a better clinical prognosis among patients with stage II and III disease. The meaning of this association is not clear and has never been reported before. However, our unexpected findings suggest that estrogens might be involved in lung carcinogenesis, probably either by acting as ER ligands and activating cell-proliferation pathways or by metabolic activation to reactive intermediates that can produce DNA adducts or cause oxidation damage, as mentioned in a recent study. ${ }^{31}$

Adenocarcinoma of the lung, which shows a weaker association with tobacco smoking than with other types of lung cancer, is also found predominantly in women, suggesting a possible role for female hormones in this form of disease. ${ }^{32,33}$ In our study the distribution of hormone receptors in NSCLCs also appeared in male patients. This phenomenon might be partly explained by the fact that estrogen could have a role in cancer in male patients. Because the enzyme aromatase (CYP19), which is expressed in many tissues outside the reproductive tract, is able to convert androgen to estrogen, ${ }^{31,34}$ local tissue production of estrogen might also occur in male patients. These results indicate that blocking the effects of estrogen might be an important therapeutic strategy to halt lung cancer progression or prevent recurrence in patients of both sexes.

From an endocrinologic point of view, the expression of $\mathrm{ER} \beta$ has been noted as more common in premenopausal and perimenopausal patients with cancer than in postmenopausal patients with breast cancer. ${ }^{29}$ In one recent study examining a large multi-institutional database, premenopausal women were found to have more advanced lung cancer and to undergo more extensive resection, yet these women had a survival advantage compared with postmenopausal women. ${ }^{21}$ However, ER status in these patients' tumors was not examined. In this study we did not find a concordance between menopause status and $\operatorname{ER} \beta$ overexpression in NSCLCs.

Our results unequivocally demonstrate that $\operatorname{ER} \beta$ can be routinely detected in archival, formalin-fixed, and paraffinembedded lung cancers by using the monoclonal antibody. This could have profound clinical implications because the level of sex hormone receptors in cancer tissue often is 


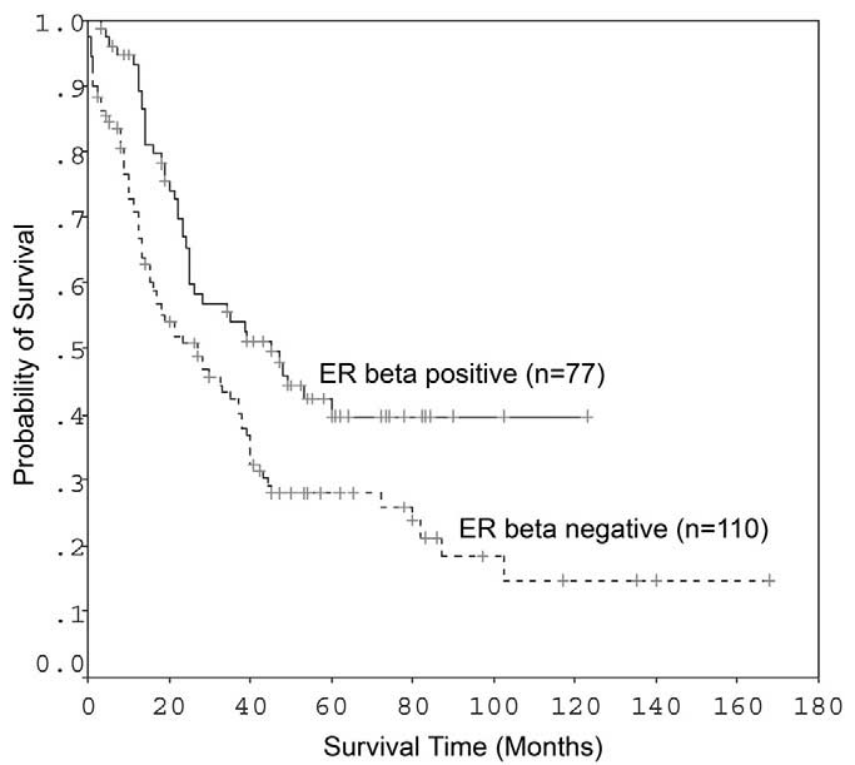

Figure 1. Survival curves in patients with stage II and III disease: surgically resected non-small cell lung carcinomas with positive $(>50 \%)$ or negative $(\leq 50 \%)$ estrogen receptor $\beta$ expression $(P=$ .004 , log-rank test). ER, Estrogen receptor.

considered as an indicator for the selection of appropriate treatment. The finding of $E R \beta$ in a wide array of nontarget neoplastic tissues might be indicative of their common role in the regulation of cancer growth, irrespective of the organ involved.

On the basis of immunohistochemistry results, the forms of $\operatorname{ER} \alpha$ expressed in our lung cancer tissues were located primarily in the cytoplasm, and the cases were few. The reason might be that lung cancer cells have little or no full-length $\mathrm{ER} \alpha$ and that the stained variant is mainly cytoplasmic. ${ }^{19}$ According to several recent reports, immunohistochemical study also failed to demonstrate $\mathrm{ER} \alpha$ nuclear expression in lung cancers. ${ }^{17,18}$ The reasons for this finding remain unclear.

In conclusion, this study is the first to demonstrate the association between ER $\beta$ overexpression and female sex, nonsmoking status, tumors of $3 \mathrm{~cm}$ or smaller, absence of lymph node metastasis, and tumors with a lower grade of differentiation in a large cohort of patients with NSCLCs by means of immunohistochemistry. Interestingly, the present results also have clinical implications because of the observation of a statistically significant correlation between survival and tumors with stage II diseases, a lower grade of differentiation, nonsmoking status, tumors without vascular invasion, and increased expression of ER $\beta$ in stage II and III NSCLCs. Thus it is strongly indicated that $\mathrm{ER} \beta$ overexpression could be a useful and statistically significant prognostic marker for surgically resected stage II and III NSCLCs.
These studies might also provide the possibility for a new type of adjuvant therapy in selected patients with lung cancer.

We thank Ms Chih-Hsin Chen for her skillful technical support. We are indebted to Ms Wan-Hui Chang and Hsuan-Yu Chen, MSc, for their assistance in statistical analysis and Mr Wen-Chen $\mathrm{Wu}$ for his help in preparation of the manuscript.

\section{References}

1. Department of Health. Vital statistics, 1971-2001. Taipei, ROC: Department of Health; 2002.

2. Jemal A, Murray T, Ward E, Samuels A, Tiwari RC, Ghafoor A, et al. Cancer statistics, 2005. CA Cancer J Clin. 2005;55:10-30.

3. Au JSK, Mang OWK, Foo W, Law SCK. Time trends of lung cancer incidence by histologic types and smoking prevalence in Hong Kong 1983-2000. Lung Cancer. 2004;45:143-52.

4. Yoshimi I, Ohshima A, Ajiki W, Tsukuma H, Sobue T. A comparison of trends in the incidence rate of lung cancer by histological type in the Osaka Cancer Registry, Japan and in the Surveillance, Epidemiology and End Results Program, USA. Jpn J Clin Oncol. 2003;33:98-104.

5. Harley RA Jr. Tobacco: In: Dail DH, Hammar SP, editors. Pulmonary pathology. 2nd ed. New York: Springer-Verlag: 1994; p. 841.

6. Liaw YP, Huang YC, Lien GW. Patterns of lung cancer mortality in 23 countries: application of the age-period-cohort model. BMC Public Health. 2005;5:22.

7. Carcangiu ML, Chambers JT. Sex steroid receptors in gynecologic neoplasms. Pathol Annu. 1992;27(suppl):121-51.

8. Ollayos CW, Riodan GP, Rushin JM. Estrogen receptor detection in paraffin sections of adenocarcinoma of the colon, pancreas, and lung. Arch Pathol Lab Med. 1994;118:630-2.

9. Green S, Walter P, Kumar V, Krust A, Bornert JM, Argos P, et al. Human estrogen receptor cDNA: sequence, expression and homology to v-erb-A. Nature. 1986;320:134-9.

10. Kuiper GG, Enmark E, Pelto-Huikko M, Nilsson S, Gustafsson JA. Cloning of a novel receptor expressed in rat prostate and ovary. Proc Natl Acad Sci U S A. 1996;93:5925-30.

11. Enmark E, Pelto-Huikko M, Grandien K, Lagercrantz S, Lagercrantz $\mathrm{J}$, Fried G, et al. Human estrogen receptor $\beta$-gene structure, chromosomal localization, and expression pattern. J Clin Endocrinol Metab. 1997;82:4258-65.

12. Paech K, Webb P, Kuiper GG, Nilsson S, Gustafsson J, Kushner PJ, et al. Differential ligand activation of estrogen receptors ER $\alpha$ and $\operatorname{ER} \beta$ at AP1 sites. Science. 1997;277:1508-10.

13. Canver CC, Memoli VA, Vanderveer PL, Dingivan CA, Mentzer RM Jr. Sex hormone receptors in non-small-cell lung cancer in human beings. J Thorac Cardiovasc Surg. 1994;108:153-7.

14. Su JM, Hsu HK, Chang H, Lin SL, Chang HC, Huang MS, et al. Expression of estrogen and progesterone receptors in non-small-cell lung cancer: immunohistochemical study. Anticancer Res. 1996;16:3803-6.

15. Kaiser U, Hoffmann J, Schilli M, Wegmann B, Klotz U, Wedel S, et al. Steroid-hormone receptors in cell lines and tumor biopsies of human lung cancer. Int J Cancer. 1996;67:357-64.

16. Brown RW, Campagna LB, Dunn JK, Cagle PT. Immunohistochemical identification of tumor markers in metastatic adenocarcinoma. A diagnostic adjunct in the determination of primary site. Am J Clin Pathol. 1997;107:12-9.

17. Di Nunno L, Larsson LG, Rinehart JJ, Beissner RS. Estrogen and progesterone receptors in non-small-cell lung cancer in 248 consecutive patients who underwent surgical resection. Arch Pathol Lab Med. 2000;124:1467-70.

18. Omoto Y, Kobayashi Y, Nishida K, Tsuchiya E, Eguchi H, Nakagawa $\mathrm{K}$, et al. Expression, function, and clinical implications of the estrogen receptor $\beta$ in human lung cancers. Biochem Biophys Res Commun. 2001;285:340-7.

19. Stabile LP, Gaither Davis AL, Gubish CT, Hopkins TM, Luketich JD, Christie N, et al. Human non-small cell lung tumors and cells derived from normal lung express both estrogen receptor $\alpha$ and $\beta$ show biological responses to estrogen. Cancer Res. 2002;62:2141-50. 
20. Mountain CF. Revisions in the international system for staging lung cancer. Chest. 1997;111:1710-7.

21. Moore KA, Mery CM, Jaklitsch MT, Hopkins TM, Luketich JD, Christie N, et al. Menopausal effects on presentation, treatment, and survival of women with non small cell lung cancer. Ann Thorac Surg. 2003;76:1789-95.

22. Beattie CW, Hansen NW, Thomas PA. Steroid receptors in human lung cancer. Cancer Res. 1985;45:4206-14.

23. Muscat JE, Richie JP Jr, Thompson S, Wynder EL. Gender differences in smoking and risk for oral cancer. Cancer Res. 1996;56:5192-7.

24. Pettersson K, Gustafsson JA. Role of estrogen receptor $\beta$ in estrogen action. Annu Rev Physiol. 2001;63:165-92.

25. Taylor AH, Al-Azzawi F. Immunolocalisation of estrogen receptor $\beta$ in human tissues. J Mol Endocrinol. 2002;24:145-55.

26. Chaudhuri PK, Thomas PA, Walker MJ, Briele HA, Das Gupta TK, Beattie CW. Steroid receptors in human lung cancer cytosols. Cancer Lett. 1982;16:327-32.

27. Kobayashi S, Mizuno T, Tobioka N, Ichimura H, Samoto T, Tanaka H, et al. Sex steroid receptors in diverse human tumors. Gann. 1982;73: $439-45$.
28. Cagle PT, Taylor LD, Schwartz MR, Ramzy I, Elder FF. Cytogenetic abnormalities common to adenocarcinoma metastatic to the pleura. Cancer Genet Cytogenet. 1989;39:219-25.

29. Jarvinen TAH, Pelto-Huikko M, Holli K, Isola J. Estrogen receptor $\beta$ is coexpressed with $\mathrm{ER} \alpha$ and PR and associated with nodal status, grade, and proliferation rate in breast cancer. Am J Pathol. 2000;156: 29-35.

30. Cheng J, Lee EJ, Madison LD, Lazennec G. Expression of estrogen receptor $\beta$ in prostate carcinoma cells inhibits invasion and proliferation and triggers apoptosis. FEBS Lett. 2004;566:169-72.

31. Stabile LP, Siegfried JM. Estrogen receptor pathways in lung cancer. Curr Oncol Rep. 2004;6:259-67.

32. Baldini EH, Strauss GM. Women and lung cancer: waiting to exhale. Chest. 1997;112:229s-34s.

33. Kirsh MM, Tashian J, Sloan H. Carcinoma of the lung in women. Ann Thorac Surg. 1982;34:34-9.

34. Simpson ER, Michael MD, Agarwal VR, Hinshelwood MM, Bulun SE, Zhao Y. Cytochromes P450 11: expression of the CYP19 (aromatase) gene: an unusual case of alternative promoter usage. FASEB J. 1997;11:29-36.

The Journal of Thoracic and Cardiovascular Surgery Conflict of Interest Policy

To assure fairness to authors submitting work for consideration in The Journal of Thoracic and Cardiovascular Surgery, a mechanism exists for managing conflicts of interest. The editor and each of the section editors complete a "Conflict of Interest" form that identifies any and all relationships with commercial and other academic entities. When the editor has a potential conflict because of a relationship with another entity or author, the editor appoints an alternate editor from among the section editors or editorial board members who assumes the entire responsibility for final decisions on the manuscript in question. The editor does not read the reviews that are submitted nor engage in discussing the manuscript prior to the final decision. When the conflict of interest involves a section editor, a "guest section editor" is appointed who fills the role normally played by the conflicted section editor. All members of the editorial board and reviewers are asked to indicate any conflict of interest when they agree to review a manuscript. 